\title{
1 RETRATO DA DOENÇA MENTAL NA COMUNICAÇÃO SOCIAL
}

\author{
| Cláudia Azevedo ${ }^{1}$ |
}

Em democracia, os media têm um papel fundamental no exercício da cidadania. Os órgãos de comunicação social são responsáveis por fazer chegar aos cidadãos informação sobre assuntos relevantes da sua vida, permitindo a reflexão, a participação pública e a tomada de decisões.

$\mathrm{Na}$ área da saúde, os jornalistas são chamados a desempenhar um papel crucial na construção e no aprofundamento de uma verdadeira literacia de saúde, suscetível de gerar ganhos no sistema e de melhorar a vida das pessoas.

Sabe-se que os media constituem mesmo a principal fonte de informação para a população em geral e para os próprios doentes em matéria de saúde mental, possuindo o poder e a capacidade de influenciar mentalidades, atitudes e comportamentos.

Mas será que o jornalismo está a cumprir o seu papel? Se a sua visão fosse obtida exclusivamente através da lente dos media, qual seria a sua opinião sobre os doentes mentais?

Uma série de estudos realizados a nível internacional mostra que os órgãos de comunicação social têm tendência a apresentar a doença mental de uma forma que promove o estigma e reforça os mitos, relacionando-a frequentemente com atos de violência, prática de crimes, imprevisibilidade e perigosidade.

A literatura revela também que a doença mental não está identificada na maior parte das vezes, como se esta fosse por si só um rótulo maligno que dispensasse mais detalhes. Além disso, o jornalista raramente ouve o doente mental como fonte, o que traduz a ideia de que este não é capaz de se expressar convenientemente, ou, pior, de que não é credível.

Será que acontece o mesmo em Portugal? Na tentativa de responder a esta questão, um estudo que realizei incluiu 436 notícias com referência a doença mental publicadas, entre 2005 e 2014, em dois jornais diários portugueses, o Jornal de Notícias (dito popular ou "de massas") e o Público (considerado de referência ou "de elite").
A principal conclusão, em linha com a literatura internacional, é que os textos jornalísticos com referência a doença mental são predominantemente relacionados com atos de violência, prática de crimes e perigosidade, sobretudo os do JN. Em cerca de 35\% dos casos, o doente mental surge como criminoso, infrator, indivíduo violento ou agressor (na verdade, de acordo com dados da Mental Health Foundation, a probabilidade de o doente mental ser vítima é 10 vezes maior do que a de perpetrar um crime violento).

Alguns dos estereótipos encontrados nos jornais nacionais são comuns aos de outros países. Além de criminoso e de vítima, o doente mental aparece muitas vezes retratado como o espírito rebelde, o narcisista, o manipulador, ou então como a vítima indefesa, o miserável, o "cromo" ou o parasita que absorve os dinheiros públicos.

Neste estudo, verifica-se ainda que apenas 9,2\% das notícias contêm declarações dos doentes e, na maior parte, citados por outrem ou no contexto de processos judiciais. Somente $23,2 \%$ das peças jornalísticas têm declarações de profissionais de saúde, nomeadamente enfermeiros. A doença mental não é identificada em cerca de um terço da amostra (30,7\%), fazendo com que os comportamentos negativos associados a uma doença mental específica, se existente, sejam abusivamente generalizados.

Vários estudos internacionais são unânimes quanto às consequências: a representação negativa da doença mental nas notícias tem uma influência perniciosa nas perceções das pessoas e na forma como se relacionam ou tencionam relacionar-se com doentes mentais, assim como tem efeitos nos próprios doentes. Ao difundir o estigma, os media certificam um rótulo que é interiorizado e que leva à diminuição da sua autoestima, a sentimentos de vergonha e de revolta, ao isolamento, à exclusão e à perda de direitos.

Submetido em 30-09-2017

Aceite em 15-11-2017

1 Mestre em Ciências da Comunicação; Pós-Graduada em Literacia de Saúde; Communication Manager no CINTESIS - Centro de Investigação em Tecnologias e Serviços de Saúde, Rua Dr. Plácido da Costa, s/n, 4200-450 Porto, Portugal, claudiaazevedo@med.up.pt 
Ao difundirem massivamente estes preconceitos, representações perversas e ideias falsas, os media estão a reforçar, a promover e a perpetuar a estigmatização e até a prejudicar o investimento na área da Saúde Mental. Não por acaso, em Portugal, esta área tem sido um "parente pobre" da Política de Saúde.

A generalização e a banalização da ligação entre doença mental e violência têm também consequências na legislação (mais coerciva), nas políticas sociais e nas respostas governamentais aos problemas mentais.

Quais são, então, as recomendações para o futuro? Desde logo, os jornalistas têm de ser sensibilizados para a necessidade de darem mais atenção ao tema da saúde mental, sobretudo no âmbito de experiências positivas cujo conhecimento público possa contribuir para combater o estigma atualmente existente. É absolutamente paradoxal que as doenças mentais, que atingem uma em cada quatro pessoas em algum momento das suas vidas, tenham uma atenção tão reduzida da comunicação social.

No seu todo, este estudo aponta ainda para a necessidade de os jornalistas darem menos ênfase às menções ou alegações de doença mental em contexto de crimes, infrações e atos violentos, de confirmarem o diagnóstico, de indicarem a doença mental em concreto e de ouvirem os doentes e associações de doentes sempre que possível.

Seriam necessários e desejáveis mais estudos e análises de conteúdo ainda mais vastas e aprofundadas para se perceber se as tendências atrás assinaladas se estendem a outros media, designadamente à televisão, nas suas vertentes informativas e de entretenimento (talk shows, filmes, novelas, etc.).

Seria igualmente interessante estudar em que medida as notícias negativas de doença mental em Portugal podem estar relacionadas com a baixa literacia e com o baixo investimento nesta área e saber se a melhoria da informação nos media poderia levar a um maior conhecimento e investimento, a uma maior prevenção e a melhores cuidados.

São, finalmente, aconselháveis em Portugal iniciativas públicas ou privadas do género da britânica "Time to Change", que lutem contra a estigmatização e contra a discriminação dos doentes mentais, envolvendo os media, como parceiros ou, mais do que isso, como aliados neste desígnio. Porque é verdadeiramente hora de mudar.

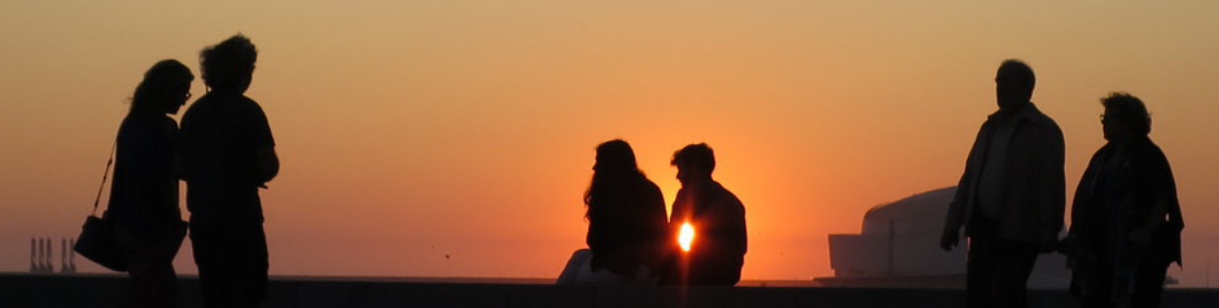

